\title{
Evaluation of Implementation of Maslow's Hierarchy of Needs to Fulfil the Needs of Freelance Journalist and Adaptation of Psychological Contract into Employment Relationship in Hong Kong
}

\section{| Vincent Hing-Po Lam |}

Senior Lecturer in International Journalism, Beijing Normal UniversityHong Kong Baptist University United International College (UIC), China

Vincent0901@yahoo.com

DOI: https://doi.org/10.47175/rissj.v1i2.50

\begin{abstract}
The large news newspaper and media corporation previously provides long-term and stable career for journalist to move up on the career path from junior reporter to become editor in chief. Maslow's hierarchy of needs has been used as the motivation paradigm to fulfil every stage of needs from physiological needs to the highest form of self-actualization needs. However, when the change of media market employment relationship and social media as the main focus of news content, more large media corporation uses contracted freelance journalist with expertise in their particular field as as finance, politics, sports, horse racing, travel, dine and wine as content contributor. The relationship between news corporation and journalist has changed from employment to partnership. Therefore, it remains in doubt whether Maslow's hierarchy of needs still hold for staff management in today media industry. In addition, freelance journalist is himself a KOL and expert in their field and their follower helps the media platform increase the readership and click rate which translates into increasing their advertising revenue. As such, there is psychological contract which consists of intrinsic (Pay) and extrinsic values (other factors) and different expectation from both party on this employment contract in this new form of partnership. The aim of this paper is to examine from freelance journalists point of view whether Maslow's hierarchy of needs applies on them and what are the extrinsic values which hold them on this employment relationship with media corporation.

KEYWORDS

psychological contract; hong kong journalists; freelance
\end{abstract}

\section{INTRODUCTION}

Maslow's hierarchy of needs (1943) is a theory of motivation which states that five categories of human needs dictate an individual's behavior. Those needs are physiological needs, safety needs, love and belonging needs, esteem needs, and selfactualization needs.

\begin{tabular}{|l|}
\hline Maslow's hierarchy of needs \\
\hline Self-actualization needs (intellectual needs, fulfilling potential, achieving targets) \\
\hline Esteem needs (Self-respect, level of status) \\
\hline Love and belonging needs (feeling wanted, sense of belonging, part of team) \\
\hline Safety needs (safe working environment, job security) \\
\hline Physiological needs (Basic needs, food and Shelter) \\
\hline
\end{tabular}


The original of psychological contract is developed by Denise (1989) which represents the mutual beliefs, perceptions and informal obligations between an employer and an employee. It sets the dynamics for the relationship and defines the detailed practicality of the work to be done. It only focuses on the written contract of employment between a company and an employee.

Denise (1998) extends the scope of Psychological contracts as they formed by beliefs about exchange agreements and may arise in a large variety of situations that are not necessary employer-employee.

(Turnley et al 2000) further defines psychological contract as social exchange relationship which covers any bonding of any social relationship beyond the traditional employer and employee. (Gautier 2015). Parallels are drawn between the psychological contract and social exchange theory

George, Christeen (2010)There are two types of contracts depending on the nature. These are relational psychological contracts and transactional psychological contracts. Transactional psychological contract is to focus more on the explicit elements of the contract. Relational psychological contract is to stress interdependence of the organization and level of social exchange. These psychological contracts tend to be longer term in nature.

The the implicit nature of the psychological contract makes it difficult to define, although there is some general consensus on its nature.

This consensus identifies psychological contracts as "promissory, implicit, reciprocal, perceptual, and based on expectations. George defines that participative management emphasizes leadership and has similarities with relational psychological contracts in their common emphasis on commitment and belief in the intrinsic values of people to want to work for something beyond than monetary reasons. Relational contracts are found to be associated with trust and increased acceptance of change.

Lam, et al (2020) states that the traditional media model needs content provider to find one set of psychological contract with third party agency and the editorial staff on the agency is to one to decide whether the content provided is suitable for the content receiver.

The aim of this paper is to look at how well a freelance journalist as content provider has communicated with their supervisor as third party agency for the formation of psychological contract. In addition, it also looks at the degree of importance of extrinsic value and how much the relationship of intrinsic value is formed on the freelance employment relationship.

\section{RESEARCH METHOD}

There is an open individual one-on-one phone discussion with 10 freelance journalists in Hong Kong. They are themselves an expert in the own field and are in freelance employment relationship with various local and foreign media. The research is anonymous because they do not want their views to affect their current employment relationship.

\section{Question Setting}

Question 1

Each journalist will be asked to rate which particular need of Maslow's hierarchy of needs they consider to be the most important factor to constitute the existing employment relationship

Question 2 
What are the elements you consider important as maintaining the psychological contract (extrinsic values)with in this employment?

Question 3

Have the company communicated with your expectation on this employment relationship?

\section{RESULT AND DISCUSSION}

Response from 1 journalist

\begin{tabular}{|l|l|}
\hline Question 1 & $\begin{array}{l}\text { Esteem needs because being a journalist on a big name newspaper } \\
\text { enhances his own personal profile }\end{array}$ \\
\hline Question 2 & Raising his own profile on CV \\
\hline Question & $\begin{array}{l}\text { Yes because normal contract on big name newspaper is difficult to } \\
\text { get but a freelance can enhance his CV }\end{array}$ \\
\hline
\end{tabular}

Response from 2 journalist

\begin{tabular}{|l|l|}
\hline & Response \\
\hline Question 1 & Physiological needs which additional income \\
\hline Question 2 & $\begin{array}{l}\text { Non-binding employment contract allows him to work on multiple } \\
\text { platforms to increase income }\end{array}$ \\
\hline Question & No \\
\hline
\end{tabular}

Response from 3 journalist

\begin{tabular}{|l|l|}
\hline & Response \\
\hline Question 1 & Safety needs which a fixed period of employment \\
\hline Question 2 & $\begin{array}{l}\text { The company has signed a two-year contract for the content } \\
\text { contribution which stabilizes his income and spending planning }\end{array}$ \\
\hline Question 3 & No \\
\hline
\end{tabular}

Response from 4 journalist

\begin{tabular}{|l|l|}
\hline Question 1 & $\begin{array}{l}\text { Self-actualization needs because this journalist covers travel content } \\
\text { in remote country fully paid by company and he himself is a travel } \\
\text { blogger }\end{array}$ \\
\hline Question 2 & $\begin{array}{l}\text { Being able to travel on most the remote countries by company's } \\
\text { money and those destinations such as North and South Pole which he } \\
\text { can never be able to afford }\end{array}$ \\
\hline Question 3 & $\begin{array}{l}\text { Yes because few are willing to visit those countries such as Iran, } \\
\text { North Korea, Syria and Myanmar so that the intention to enter this } \\
\text { contract has been well-communicated }\end{array}$ \\
\hline
\end{tabular}

Response from 5 journalist

\begin{tabular}{|l|l|}
\hline & Response \\
\hline Question 1 & Physiological needs with additional income \\
\hline Question 2 & Flexible working hour because he is doing his Phd \\
\hline Question 3 & $\begin{array}{l}\text { Yes as the company realizes that study in his own priority and the } \\
\text { additional income from this job is to subsidize his study }\end{array}$ \\
\hline
\end{tabular}


Response from 6 journalist

\begin{tabular}{|l|l|}
\hline & Response \\
\hline Question 1 & Love and belonging needs \\
\hline Question 2 & $\begin{array}{l}\text { He is a retired person with 40 years in media industry. Being able to } \\
\text { work as a columnist allows him to continue to connect with old } \\
\text { friend and circle }\end{array}$ \\
\hline Question 3 & $\begin{array}{l}\text { Yes because the freelance pay is so minimal as compared his own } \\
\text { wealth }\end{array}$ \\
\hline
\end{tabular}

Response from 7 journalist

\begin{tabular}{|l|l|}
\hline & Response \\
\hline Question 1 & Self-actualization needs \\
\hline Question 2 & $\begin{array}{l}\text { He is an academic and publishing articles on leading newspaper helps } \\
\text { him to improve his academic profile for promotion in university }\end{array}$ \\
\hline Question & $\begin{array}{l}\text { Yes because the additional pay needs to report to University and it is } \\
\text { does not justify the extra amount of time for so little money of } \\
\text { outside practice }\end{array}$ \\
\hline
\end{tabular}

Response from 8 journalist

\begin{tabular}{|l|l|}
\hline & Response \\
\hline Question 1 & Safety needs (safe working environment, job security) \\
\hline Question 2 & A freelancer has no promotion chance and can avoid office politics \\
\hline Question 3 & $\begin{array}{l}\text { Yes because the company originally offered a normal employment } \\
\text { contract but both parties agree on this flexible term }\end{array}$ \\
\hline
\end{tabular}

Response from 9 journalist

\begin{tabular}{|l|l|}
\hline & Response \\
\hline Question 1 & Physiological needs (Basic needs, food and Shelter) \\
\hline Question 2 & $\begin{array}{l}\text { He was a full time employee and was made reluctant due to } \\
\text { restructuring. He has been hired back by the same company but starts } \\
\text { to be paid per piece of work }\end{array}$ \\
\hline Question & $\begin{array}{l}\text { Yes because the change of employment model is due to company } \\
\text { cost cutting and restructuring }\end{array}$ \\
\hline
\end{tabular}

Response from 10 journalist

\begin{tabular}{|l|l|}
\hline Question 1 & Sesponse \\
\hline Question 2 & $\begin{array}{l}\text { He runs a property investment company and becoming a freelance to } \\
\text { cover property news helps with his profile and reputation on course }\end{array}$ \\
\hline Question 3 & $\begin{array}{l}\text { Yes he made a clear point that he uses the company's platform for } \\
\text { self-advertising and received small amount of article publishing fee } \\
\text { as this is a mutual benefit }\end{array}$ \\
\hline
\end{tabular}




\section{Analysis}

\begin{tabular}{|l|l|}
\hline \multicolumn{1}{|c|}{ Maslow's hierarchy of needs } & \\
\hline $\begin{array}{l}\text { Self-actualization needs (intellectual needs, fulfilling potential, } \\
\text { achieving targets) }\end{array}$ & 3 \\
\hline Esteem needs (Self-respect, level of status) & 1 \\
\hline $\begin{array}{l}\text { Love and belonging needs (feeling wanted, sense of belonging, part of } \\
\text { team) }\end{array}$ & 1 \\
\hline Safety needs (safe working environment, job security) & 2 \\
\hline Physiological needs (Basic needs, food and Shelter) & 3 \\
\hline
\end{tabular}

\begin{tabular}{|l|l|l|l|}
\hline & $\begin{array}{l}\text { Intrinsic } \\
\text { Value of } \\
\text { psychologic } \\
\text { al contract } \\
\text { (Physiologic } \\
\text { al Needs) }\end{array}$ & $\begin{array}{l}\text { Extrinsic Value of } \\
\text { psychological contract }\end{array}$ & $\begin{array}{l}\text { Have the company } \\
\text { communicated with your } \\
\text { expectation on this } \\
\text { employment relationship? }\end{array}$ \\
\hline Journalist 1 & & Esteem needs & Yes \\
\hline Journalist 2 & $\mathrm{x}$ & & N/A \\
\hline Journalist 3 & & Safety needs & N/A \\
\hline Journalist 4 & & Self-actualization needs & Yes \\
\hline Journalist 5 & $\mathrm{x}$ & & Yes \\
\hline Journalist 6 & & Love and belonging needs & Yes \\
\hline Journalist 7 & & Self-actualization needs & Yes \\
\hline Journalist 8 & & $\begin{array}{l}\text { Safety needs (safe working } \\
\text { environment, job security) }\end{array}$ & Yes \\
\hline Journalist 9 & $\mathrm{x}$ & & Yes \\
\hline Journalist 10 & & Self-actualization needs & \\
\hline
\end{tabular}

\section{CONCLUSION}

Maslow's hierarchy of needs outline five stages of needs for individual needs of an employee in a company. Despite that freelance journalists do not have promotion opportunity inside company, it does not mean that their needs from the freelance job only fulfills their physiological needs because every individual has different expectation on this employment relationship. They seek for flexible working hour, fringe benefit from the employment, lack of office politics relationship maintain with the industry, sponsored travel, raising his own profile.

Only 3 out of 10 freelance journalists do the job simply for income and 7 out of 10 respondents seek for various reasons which constitute the extrinsic values of psychological contract on this form of employment relationship.

Only 8 out of 10 freelance journalists have communicated the reason of what it takes to maintain on this casual employment relationship. Therefore, the human resources department may need to map out job expectation of the extrinsic value and expectation from freelance journalistic to maintain the long-lasting stable employment relationship as pay alone is not the primary concern of individual employee. 


\section{REFERENCES}

Vincent Lam, LO Suk Fun. "Evaluation of the Formation of Intrinsic Values of Psychological Contract of Hong Kong You Tuber and their Viewers ". International Journal of Humanities Social Sciences and Education (IJHSSE).

Maslow, A. H. (1943). A theory of human motivation. Psychological Review.

Rousseau, D. M. (1989). Psychological and implied contracts in organizations. Employee Responsibilities and Rights Journal.

Rousseau, Denise M. (1998). "The 'Problem' of the Psychological Contract Considered". Journal of Organizational Behavior.

Van den Heuvel, Sjoerd, and Rene Schalk. "The Relationship Between Fulfillment Of The Psychological Contract And Resistance To Change During Organizational Transformations.". Journal of Experimental. 